\title{
The Effect of Halal Labels on Purchasing Decisions for Wardah Cosmetics of Students Islamic Building School of Jagad 'Alimussirry
}

\author{
G. L. Muharromah ${ }^{1}$, R. Rahmatika ${ }^{2}$ \\ ${ }^{1}$ Islamic Building School of Jagad Alimussirry Surabaya, Indonesia \\ ${ }^{2}$ Department of Biology, State University of Malang \\ Email: gabrielemuharromah16081194031@mhs.unesa.ac.id
}

\begin{abstract}
The purpose of this study was to determine the effect of the halal label on purchasing decisions for students of the Jagad 'Alimussirry Islamic Boarding School. The research method used is quantitative research. The sample in this study were 47 respondents, using a purposive sampling technique. The data analysis used is simple linear regression. The results showed that the halal label variable had a significant effect on the purchasing decision for Wardah cosmetics with a significant value of 0.000 . The contribution of the independent variable, namely the halal label, affects the dependent variable, namely the purchase decision by $39.3 \%$. While the remaining $60.7 \%$ is influenced by other variables not examined in this study.
\end{abstract}

Keywords: buying decision; halal cosmetics; halal label

\section{INTRODUCTION}

Indonesia is nicknamed the country with the largest Muslim population in the world with a Muslim population of 219.96 million (Pew Research, 2015). The number of Muslim consumers in Indonesia reaches 87.18 percent of the population (Prayogi, 2019). As a Muslim consumer consuming goods should pay attention to halal and haram goods to be consumed. Halal is designated for everything that is good, holy, and does not contain elements that are prohibited in Islam so that it can be consumed by a Muslim.

Apart from being careful in consuming food and drinks, it is also necessary to be careful in using cosmetics. In the use of cosmetics that need to be considered, namely the quality and ingredients contained in cosmetics, namely the element of halalness and the purity of the ingredients. In accordance with the Law of the Republic of Indonesia Number 33 of 2014 concerning Guarantee of Halal Products, special care is needed in selecting and using cosmetic products. This is because it can affect the validity of a Muslim's worship. Therefore, based on this law, products that have obtained halal certification from the Indonesian Ulema Council (MUI) can include a halal label on their products.

Currently, there are also dangerous illegal cosmetics circulating in the market with the sale value of illegal cosmetics reaching Rp. 134.13 trillion. Halal cosmetics are the answer to the concerns of Muslim women who want to look beautiful, but do not violate religious teachings. In 2016, data from LPPOM MUI contained 48 companies with a total of 5,254 halal cosmetic products. One of the most popular halal cosmetic brands in Indonesia is Wardah (Nandini, 2018). Wardah cosmetic users, there are several groups, from teenagers to housewives. Likewise among the students of 
Jagad 'Alimussirry Islamic Boarding School (PPJA).

Based on a pre-research survey at PPJA through a questionnaire with student respondents, of the 40 students, there were only four students who had never used Wardah cosmetic products. The average number of Wardah cosmetics used by PPJA students has more than one type of Wardah product used. This shows that many PPJA students use cosmetic products from Wardah. Based on this background, this study will examine the effect of the halal label on the decision to purchase Wardah cosmetic products for students at the Jagad 'Alimussirry Islamic Boarding School.

\section{LITERATURE REVIEW}

\section{A. Halal Cosmetics}

Based on the MUI Fatwa Number 26 of 2013 concerning the Legal Standards for Cosmetics Products and Their Use, it states that the use of legal cosmetics is allowed for decorative purposes, but must meet the requirements, namely, the materials used are halal and holy, intended for purposes that are permitted in syar'i and are not harmful.

\section{B. Halal Label}

Labels are text, pictures or both printed on a product container or packaging. The word Halal is a term in Arabic which means permitted or permitted. Etymologically halal means "things that can and can be done because they are free or not bound by the provisions that prohibit them" (Widyaningrum, 2019). The indicators used on halal labels that have been listed in Government Regulation Number 69 of 1999 concerning Halal Labels and Food Ads, namely: pictures, writing, a combination of images and writing, and attached to the packaging.

\section{Buying decision}

The purchasing decision making process according to Kotler and Armstrong (2009) consists of five stages, namely: recognition of needs, information search, evaluation of alternatives, purchase decisions and postpurchase behavior.

\section{METHOD}

In this research, the type of research used is quantitative research. This study uses a survey method intending to collect information in a population. The data that can be obtained from this research is through questionnaires, observations, and interviews. The research was conducted at the Pondok Pesantren Putri Jagad 'Alimussirry which is located at Jl. Jetis Kulon VI No 16 A Wonokromo Surabaya.

The population used by all students at the Jagad 'Alimussirry Islamic Boarding School was 89 students. Based on the population, the sample was calculated using the Slovin formula and obtained the results of 47 respondents. The sampling technique used was a non-probability sampling method with a purposive sampling design. The criteria set by the researcher were: Respondents were students of the Jagad 'Alimussirry Islamic Boarding School and users of Wardah cosmetics.

Data analysis using simple linear regression. The instrument test was carried out by using the validity test and the reliability test. Hypothesis testing uses the t-test (partial) and the determinant efficiency test. The data processing process in this study uses SPSS Version 23.00 which is useful for simplifying and accelerating data processing.

\section{RESULT AND DISCUSSION}

The results showed that the effect of the halal label (X) on purchasing decisions (Y) has a value of 5.403 and a significance value of 0.000 . This study shows that there is a significant effect of the halal label variable on the decision to purchase Wardah cosmetic products for students of the Jagad 'Alimussirry Islamic Boarding School. This research is in line with research conducted by Nurhijriah and Saleh (2018) that the halal label influences consumer purchasing decisions.

The decision to purchase Wardah cosmetic products for students of the Jagad 'Alimussirry 
Islamic Boarding School was influenced by the existence of a halal label printed on Wardah products. With this halal label, consumers can identify the halalness of the product and provide confidence in the quantity and quality of the product. Based on the research that has been done, it is known that the coefficient of determination is 0.393 , this means that the contribution of the independent variable, namely the halal label (X), affects the dependent variable, namely the purchase decision (Y) of $39.3 \%$. While the remaining $60.7 \%$ is influenced by other variables not examined in this study.

At Pondok Pesantren Jagad 'Alimussirry, there are several studies, one of which discusses Islamic economics. In the study of Islamic economics it is explained about consumption in Islam, so that when carrying out consumption activities, it is not only concerned with desire. But also need to prioritize needs. In carrying out consumption activities, it is also necessary to pay attention to the goods to be consumed. The halalness of the goods to be consumed needs to be considered. The behavior regarding consumption in Islam has been regulated in the Qur'an, one of which is found in Sura al A'raf verse 157 which means

"... He (Prophet Muhammad) ordered them to the ma'ruf and prevented them from the unbelievers, and made lawful for them everything that was good and forbade them all that was bad."

Based on surah al A'raf verse 157 it is explained that humans are ordered to consume things that are halal thayyiban. Halal means that which is not prohibited by sharia, while thayyiban includes three things, namely, the status is halal, does not endanger body and spirit, and is fit for consumption. So that in consuming cosmetic products, it is necessary to pay attention to their halalness. This is because everything lawful can provide goodness or benefit to those who consume it.

\section{CONCLUSION}

Based on the results of research on the effect of the halal label on the decision to purchase Wardah cosmetics for students of the Jagad 'Alimussirry Islamic Boarding School, it shows that the t-value is 5.403 and the significant value is 0.000 . These results were obtained by performing simple regression analysis. Based on these results, it can be concluded that the halal label variable has a positive and significant effect on purchasing decisions.

\section{REFERENCES}

[1] Kotler and Keller. 2009. Marketing Management Volume 1 Edition 13. Jakarta: Erlangga

[2] Indonesian Ulema Council. 2013. MUI Fatwa Number 26 of 2013 concerning Halal Standards for Cosmetic Products and Their Use. Available in https://www.mui.or.id_accessed on 5 December 2019

[3] Nandini, Widya. 2018. The Momentum of Local Cosmetics Shows Off. Available in https://www.katadata.co.id accessed on 5 December 2019

[4] Nurhijriah and Saleh, G. 2018. The Effect of Halal Labels on Cosmetics on Purchasing Decisions. Communiverse Journal of Communication Science. Volume 3 Number 2.

[5] Pew Research Center. 2015. The Countries With The 10 Largest Cristian Populations and The 10 Largest Muslim Populations. Available in https://www.pewresearch.org accessed on 5 December 2019

[6] Prayogi, 2019., Minister of Religion: Awareness of Public Consumption of Halal Products Increases. Available in http://www.m.republika.co.id, accessed on 19 October 2019

[7] President of the Republic of Indonesia. 1999. Government Regulation Number 69 of 1999 , Available at Access https://www.itjen.kemenag.go.id. Accessed on 12 December, 2019.

[8] President of the Republic of Indonesia. 2014. Law of the Republic of Indonesia Number 33 of 2014 concerning Guarantee of Halal Products. Available in https://www.dpr.go.id. Retrieved 12 December, 2019. 
[9] Widyaningrum, PW 2019. The Influence of Halal Label, Halal Awareness, Advertising, and Celebrity Endorsers on Cosmetics Purchase Interest through Perception Variable as Mediation (Study on the Academic Community of Muhammadiyah University of Ponorogo). Journal of Capital Economics and Management. Volume 2 Number 2. 